\title{
Peningkatan Kualitas Ikan Koi (Cyprinus carpio) di Kelompok PBC Fish Farm di Kecamatan Cisaat, Sukabumi
}

\section{(The Improvement of Koi Fish (Cyprinus carpio) Quality in the PBC Fish Farmer Group, Cisaat Subdistrict, Sukabumi)}

\author{
Yuli Andriani ${ }^{*}$, Asri Peni Wulandari ${ }^{2}$, Rusky Intan Pratama ${ }^{1}$, Irfan Zidni ${ }^{1}$ \\ 1 Departemen Perikanan, Fakultas Perikanan dan Ilmu Kelautan Universitas Padjadjaran \\ Jln. Raya Jatinangor Km 21, Sumedang 45363. \\ 2 Departemen Biologi, Fakultas Matematika dan Ilmu Pengetahuan Alam, Universitas Padjadjaran \\ Jln. Raya Jatinangor Km 21, Sumedang 45363. \\ Penulis korespondensi: yuliyusep@yahoo.com \\ Diterima Januari 2018/Disetujui Desember 2018
}

\begin{abstract}
ABSTRAK
Berbagai ikan hias, seperti ikan koi dan komet merupakan komoditas andalan dari Desa Nagrak, Kecamatan Cisaat, Kabupaten Sukabumi, Jawa Barat. Para pembudidaya ikan hias di desa ini telah berkelompok dalam bentuk pokdakan yang bernama Pokdakan PBC Fish Farm yang diketuai oleh Ikral Panutan. Masalah kualitas warna ikan hias yang masih dalam skala rendah merupakan masalah yang dihadapi oleh anggota kelompok ini. Hal ini ditandai dengan masih banyaknya hasil panen ikan koi dengan kualitas warna yang tidak begitu cerah dan tidak merata atau berpola. Tujuan dari kegiatan ini adalah untuk peningkatan kualitas ikan hias koi dengan cara penggunaan pakan berbahan tambahan serbuk spirulina sehingga dapat memberikan nilai tambah pada produksi ikan hias yang dihasilkan. Kegiatan pemberdayaan masyarakat telah dilakukan selama 4 bulan sejak Juli-Oktober 2016. Tahapan pelaksanaan meliputi: 1) Sosialisasi dan inisiasi, 2) Pelatihan manajemen budi daya ikan, metode kultur spirulina dan cara pembuatan pakan dengan menggunakan metode diskusi dan demonstrasi plot; dan 3) Evaluasi dan monitoring. Hasil yang diperoleh adalah secara umum kegiatan ini mendapatkan respons dan hasil yang baik dari peserta penyuluhan, terbukti dengan adanya kemampuan pembudidaya dalam melakukan kultur spirulina untuk selanjutnya diaplikasikan sebagai campuran pakan ikan dapat menghasilkan peningkatan kualitas warna ikan koi. Penggunaan pakan berbahan tambahan serbuk spirulina pada ikan koi di Pokdakan PBC Fish Farm terbukti dapat meningkatkan kualitas warna, serta memberikan nilai tambah ekonomi sebesar 50-100\% di mana harga jualnya meningkat dari semula Rp 3.000 menjadi Rp 4.500-6.000 per ekor.
\end{abstract}

Kata kunci: ikan koi, karotenoid, kualitas warna, pertumbuhan, tepung spirulina

\begin{abstract}
Various ornamental fish, such as koi and comet is a mainstay commodity from Nagrak Village, Cisaat District, Sukabumi Regency, West Java. The ornamental fish farmers in this village have been grouped in the form of pokdakan called "Pokdakan PBC Fish Farm", which is chaired by Ikral Panutan. The main problem faced by members of this group is the color of the ornamental fish which still in low grade in quality. The purpose of this activity was to improve the quality of koi ornamental fish by using additional powder feed spirulina so that it can give added value to the production of ornamental fish produced. Community empowerment activities have been conducted for 4 months from July to October 2016. Steps of implementation include: 1) Socialization and initiation stage; 2) Training about fish culture management, spirulina culture method and feeding method using discussion method and demonstration plots; and 3) Evaluation and monitoring phase. The results obtained are generally these activities get the response and good results from the extension participants, as evidenced by the ability of farmers in cultured spirulina henceforth be applied as a mixture of fish feed can result in improved color quality of koi. Use of spirulina powder feed additional material on Cyprinus carpio of PBC Fish Farm proven to improve color quality, and provide value-added economy by $50-100 \%$ with the selling price ranging from IDR 3.000 , per head to IDR $4.500-6.000$ per tail.
\end{abstract}

Keywords: carotenoids, growth, koi fish, spirulina powder, quality color 


\section{PENDAHULUAN}

Ikan koi (Cyprinus carpio koi) merupakan salah satu ikan hias yang memiliki bentuk tubuh dan warna yang indah sehingga bernilai ekonomis tinggi. Indikator keindahan pada ikan hias dapat dilihat pada warna yang cemerlang, bentuk dan kelengkapan fisik, perilaku, serta kondisi kesehatan atau staminanya (Effendie 1979). Selain itu ikan koi ini sering dijadikan hiasan akuarium dan merupakan konsumsi seni bagi peminatnya (Lesmana 2007).

Warna merupakan salah satu alasan ikan hias diminati oleh masyarakat, sehingga pembudidaya perlu mempertahankan warna ikan hias, yaitu dengan cara memberikan pakan yang mengandung pigmen warna. Warna pada ikan disebabkan adanya sel kromatofora yang terdapat pada bagian kulit dermis. Karotenoid adalah komponen alami utama pembentuk pigmen warna yang memberikan pengaruh cukup baik pada warna merah dan oranye (Budi 2001). Menurut Hidayat dan Saati (2006) terdapat bahan makanan yang mengandung zat karotenoid di antaranya adalah wortel, ubi, jagung, labu kuning, dan sayuran hijau lain.

Sumber karotenoid lainnya juga dapat berasal dari spirulina, karena spirulina memiliki kandungan phycocyanin, chlorophyll-a, dan karoten (Sasson 1991; Vonshak 1997). Karoten tersusun atas xantophyll (37\%), $\beta$-carotene (28\%), dan zeaxanthin (17\%) (Tongsiri et al. 2010). Pemberian sumber pigmen warna pada pakan ikan merupakan salah satu usaha yang dilakukan untuk mendapatkan warna cerah yang merata pada ikan. Banyak penelitian yang menunjukkan pengaruh pemberian spirulina terhadap warna ikan hias maupun udang atau lobster (Amin 2012). Penelitian James (2010), menyatakan bahwa pemberian pakan yang mengandung spirulina sebanyak $8 \%$ efektif dalam meningkatkan pigmentasi warna pada ikan red swordtail (Xiphophorus helleri). Menurut Noviyanti et al. (2015) penambahan tepung spirulina sebanyak $1,2 \%$ pada pakan buatan memberikan pengaruh sangat nyata terhadap peningkatan intensitas warna dan merupakan hasil tertinggi pada peningkatan intensitas warna ikan mas koki.

Kelompok mitra yang terlibat adalah Pokdakan PBC Fish Farm yang bergerak dalam budi daya ikan hias, serta beranggotakan 14 orang. Kelompok ini telah bergerak dalam usaha perikanan sejak tahun 2012 dan mendistribusikan ke daerah Jakarta, Bandung, Makassar, dan Yogyakarta. Khalayak sasaran yang dianggap strategis karena pembudidaya ikan hias dan ikan konsumsi ini aktif melakukan kegiatan budi daya ikan, namun masih terkendala pada kualitas warna produk ikan dan volume produksi yang dihasilkan masih terbatas. Data 3 tahun terakhir terlihat bahwa produksi benih ikan koi pada tahun 2015 sebanyak $288 \mathrm{~kg}, 2016$ sebanyak 279 kg, dan pada tahun 2017 sebanyak 281 kg ukuran $12-14 \mathrm{~cm}$.

Kegiatan ini bertujuan untuk memberikan solusi bagi kelompok budi daya, sekaligus menjadi inisiasi bagi terbentuknya kelompok pembudidaya ikan hias baru dengan memberikan gambaran tentang manajemen budi daya dan pemberian pakan yang mampu meningkatkan kualitas warna pada ikan hias, sehingga dapat memberikan nilai tambah pada produksi ikan hias yang dihasilkan. Melalui kegiatan ini diharapkan pemberdayaan ekonomi yang ada di pokdakan PBC Fish Farm dapat mencapai tujuan dan memberikan manfaat yang optimal dan meningkatkan animo masyarakat untuk mengembangkan budi daya ikan hias.

\section{METODE PELAKSANAAN KEGIATAN}

\section{Waktu dan Tempat}

Kegiatan ini dilakukan selama 4 bulan, JuliOktober 2016 di Komunitas pembudidaya ikan PBC Fish Farm Desa Nagrak, Kecamatan Cisaat, Kabupaten Sukabumi, Jawa Barat (Gambar 1).

\section{Alat dan Bahan}

Bahan yang diperlukan dalam kegiatan ini berupa ikan koi, pakan ikan berupa pakan komersial dengan kandungan protein 35\%, dan tepung spirulina yang disuplai dari Laboratorium Mikrobiologi, Fakultas Matematika dan Ilmu Pengetahuan Alam, Universitas Padjadjaran. Peralatan yang diperlukan di antaranya adalah timbangan, plastik, wadah penjemuran, bambu, dan waring (untuk pemeliharaan ikan).

\section{Metode Pelaksanaan dan Analisis Data}

Pelaksanaan kegiatan secara penerapan ipteks menggunakan pendekatan partisipatif dan penyelesaian masalah berbasis potensi yang ada di wilayah lokasi program. Kegiatan utama meliputi: 1) Sosialisasi dan inisiasi; 2) Pelatihan manajemen budi daya ikan, metode kultur spirulina, dan cara pembuatan pakan dengan menggunakan metode diskusi dan demonstrasi plot; dan 3) Evaluasi dan monitoring. 


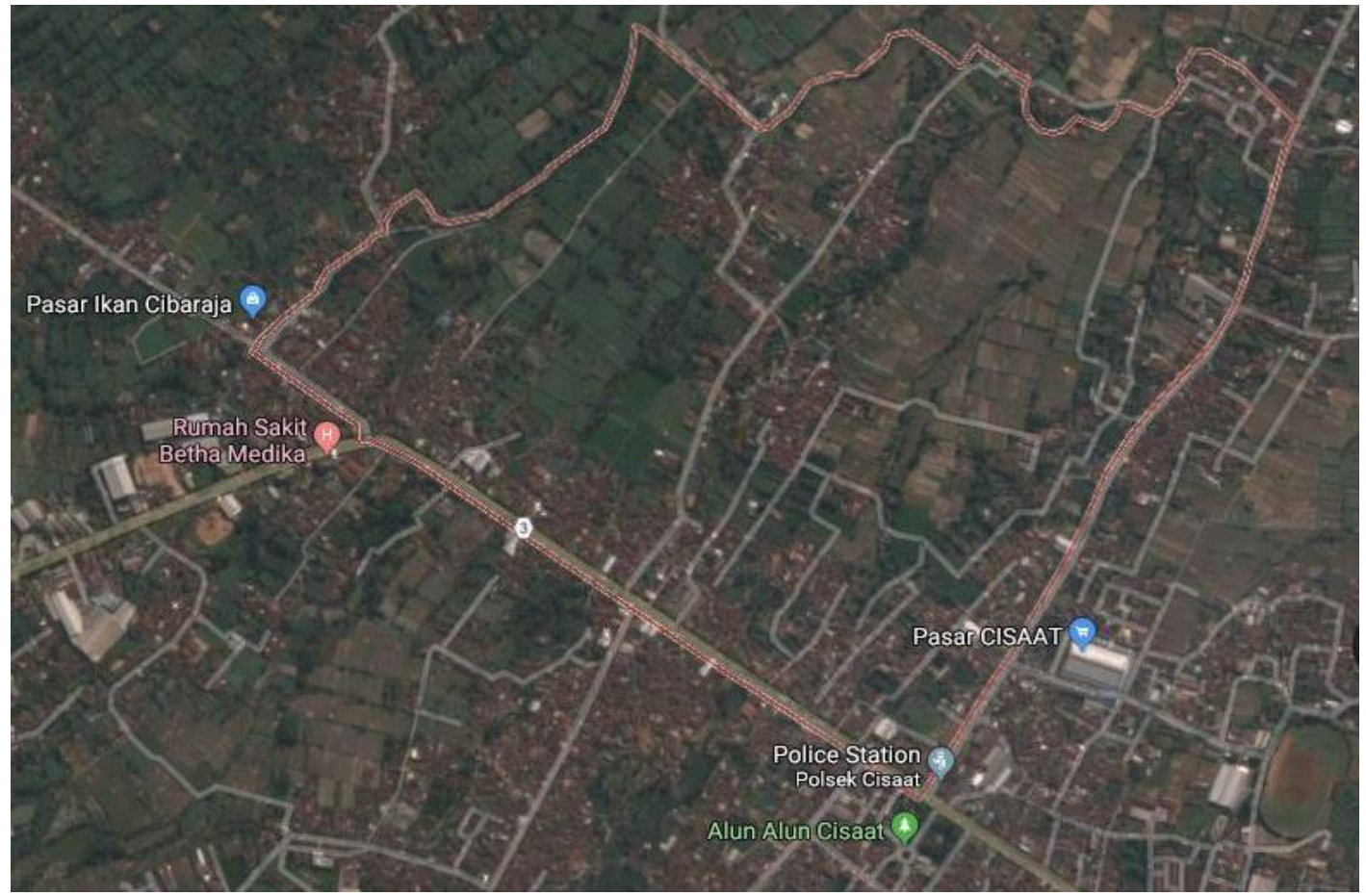

Gambar 1 Lokasi kegiatan pengabdian kepada masyarakat.

Survei awal dilakukan untuk pemetaan permasalahan dan kebutuhan yang diperlukan dalam persiapan tahapan berikutnya dengan cara survei langsung ke lokasi mitra dan masyarakat dan menyelenggarakan Forum Group Discussion (FGD). Pelatihan berupa ceramah, diskusi, dan praktik sesuai dengan tema alih teknologi. Pelatihan dilakukan dengan memberikan penjelasan tentang proses penyiapan spirulina dan pemeliharaan ikan koi yang baik dan diikuti dengan praktik. Metode penyampaian yang digunakan melalui pendekatan andragogi sehingga diharapkan terjadi interaksi yang intensif antara peserta dengan fasilitator. Pada akhir penjelasan peserta pelatihan diberi kesempatan untuk bertanya dan berdiskusi terkait dengan masalah pembuatan spirulina dan metode pemberiannya selama proses pemeliharaan ikan.

Setelah penyuluhan, dilakukan kegiatan pendampingan kelompok hingga akhir program. Pendampingan juga dilakukan melalui diskusi dan praktik dari program yang telah disampaikan pada kegiatan pelatihan, serta monitoring dan evaluasi (melalui survei dan diskusi) dengan sasaran penerima program. Pihak perguruan tinggi yang diwakili dosen dan mahasiswa bertugas sebagai fasilitator.

Metode evaluasi yang digunakan di antaranya adalah dari pengisian kuisioner mengenai sarana dan prasarana yang digunakan selama penyuluhan, kejelasan penyampaian materi oleh penyuluh, penguasaan materi penyuluh, kemam- puan komunikasi lisan dan interaksi pemateri dengan peserta penyuluhan, kemampuan pemateri dalam menjawab pertanyaan, kejelasan suara dan intonasi pemateri dalam menyampaikan materi pelatihan, kesesuaian materi yang diberikan dengan kebutuhan/permasalahan yang dihadapi sehari-hari, manfaat materi yang diberikan terhadap penerapannya di kemudian hari, potensi penerapan materi yang diberikan untuk dikembangkan di daerah masing-masing, modul yang diberikan isi materinya mudah dipahami dan menarik, alokasi waktu selama keseluruhan penyuluhan, dan metode penyampaian materi yang dilakukan.

\section{HASIL DAN PEMBAHASAN}

\section{Hasil Kegiatan Pelatihan}

Jumlah peserta yang hadir mengikuti pelatihan adalah sebanyak 20 orang. Respons para pembudidaya ikan hias terlihat antusias dan tertarik dengan materi kegiatan yang diberikan. Gambar 2 menunjukkan pemberian materi pelatihan dalam bentuk slide dan power point (PPT).

Para peserta pelatihan juga sangat tertarik terhadap materi yang diberikan, hal ini terlihat dari adanya proses diskusi dari peserta untuk menanyakan beberapa hal terkait dengan penggunaan spirulina dalam pakan dan cara pemberiannya. Demikian pula pada saat dilaksanakan 

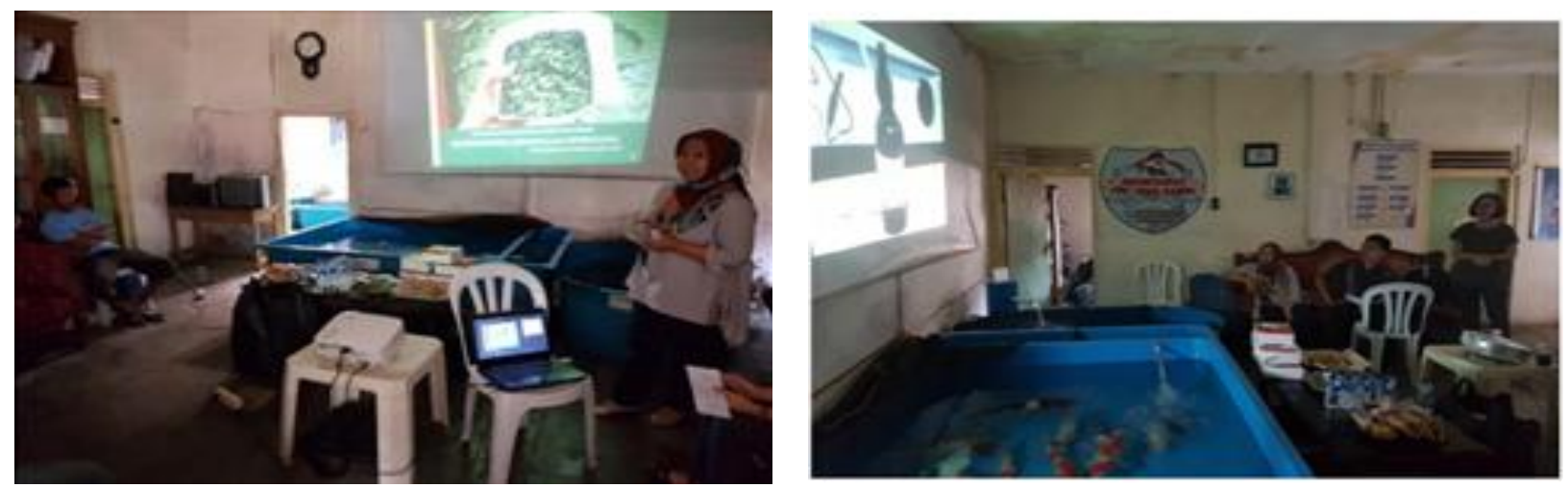

Gambar 2 Pelaksanaan pelatihan.

sesi demonstrasi dan praktik pembuatan pakan, peserta penyuluhan berpartisipasi aktif dan mengikuti semua proses dengan rasa ingin tahu yang tinggi.

\section{Proses Pembuatan Pakan Ikan}

Gambar 3 merupakan tahapan dalam pembuatan pakan ikan koi dengan penambahan spirulina yang dilakukan oleh peserta pelatihan.

\section{Proses Pendederan Ikan Koi}

Pada saat aplikasi penggunaan spirulina dalam pakan, peserta penyuluhan dengan sukarela membuat wadah budi daya dan aktif melakukan kegiatan pemberian pakan pada ikan koi pada masa pendederan. Kegiatan ini dilakukan di kolam milik ketua kelompok. Tahapan pendederan ikan dimulai dari melakukan skrining, ikan yang digunakan berukuran $7-9 \mathrm{~cm}$ dengan kepadatan 50 ekor per jaring berukuran $2 \times 2 \times 1 \mathrm{~cm}^{3}$. Menurut Murtidjo dan Agus (2011) proses pendederan ikan memilliki beberapa tahapan ukuran panen di antaranya adalah 3-5, 5-7, 7-9, dan 9-12 cm disesuaikan dengan target pembudidaya. Penyiapan ikan sebelum dipindahkan ke kolam pendederan, dipelihara di kolam induk, sedangkan kolam untuk pelaksanaan budi daya dilakukan di kolam yang lebih besar. Aplikasi pemberian pakan ikan yang mengandung serbuk spirulina dilakukan di kolam pendederan.

\section{Hasil Kegiatan Praktik dan Pendampingan}

Hasil kegiatan pendampingan menunjukkan adanya perbedaan hasil pendederan ikan koi, seperti yang ditampilkan pada Gambar 4. Berdasarkan kualitas hasil pendederan ikan koi yang diberi pakan spirulina, terlihat kualitas warnanya meningkat dan semakin cemerlang. Pengamatan secara visual oleh para pembudidaya menunjukkan bahwa kualitas warna koi yang diberi pakan spirulina termasuk Grade A hal ini

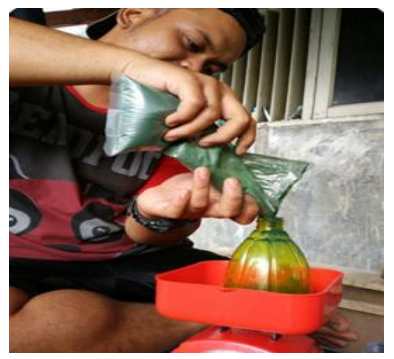

a

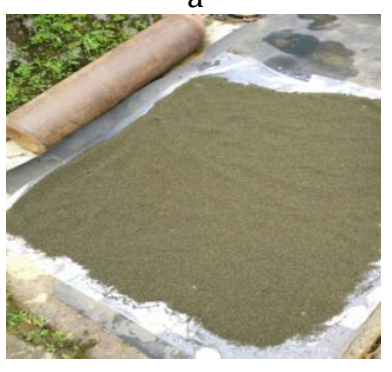

c
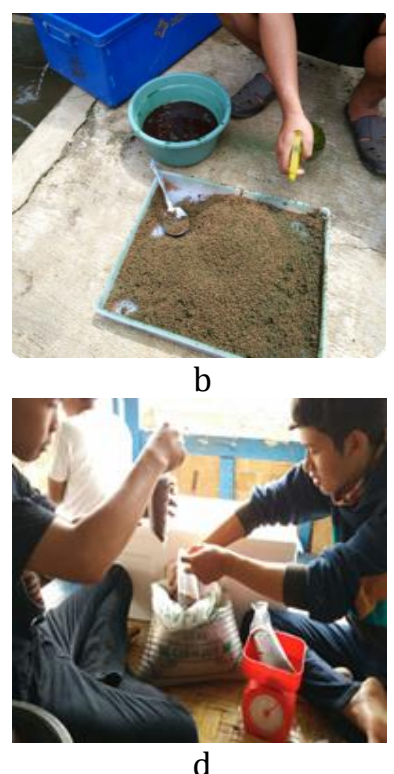

d

Gambar 3 Tahapan pembuatan pakan oleh peserta penyuluhan di PBC Fish Farm; a) Penimbangan spirulina; b) Spray pelet dengan spirulina; c) Penjemuran; dan d) Penimbangan dan pengepakan pakan sesuai kebutuhan ikan.

dipengaruhi oleh kandungan karatenoid pada spirulina. Bahan lain yang mengandung karatenoid di antaranya adalah penambahan tepung bunga marigold dalam pakan buatan terhadap kualitas warna ikan koi yang memberikan kualitas warna yang lebih baik dibandingkan dengan tanpa pemberian tepung bunga marigold (Kusuma 2012). Terjadi peningkatan harga benih ikan koi setelah pemberian tepung spirulina dimana harga jualnya meningkat dari semula Rp 3.000 menjadi Rp 4500-6000 per ekor.

\section{Respons Masyarakat dari Kegiatan}

Sebanyak $80 \%$ peserta penyuluhan mengisi skala "baik" pada seluruh kategori yang tertera pada metodologi. Berdasarkan hasil kegiatan dan kuisioner tersebut dapat dilihat bahwa kegiatan 


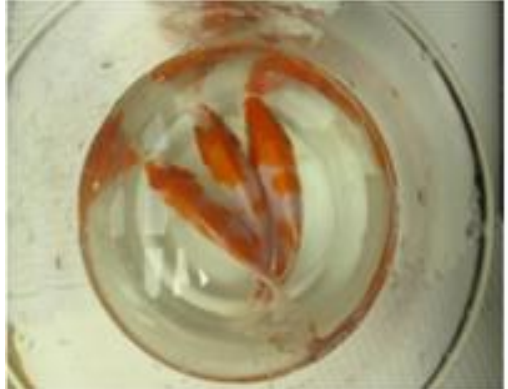

Warna ikan tanpa pemberian spirulina

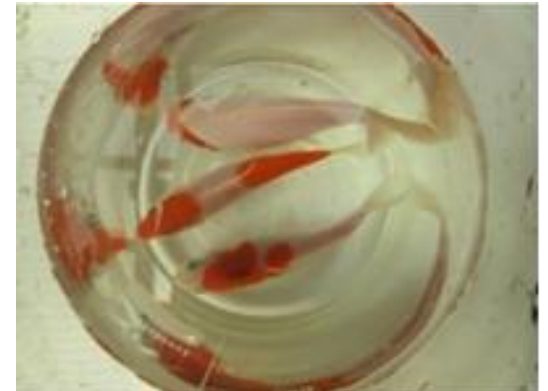

Warna ikan dengan pemberian spirulina

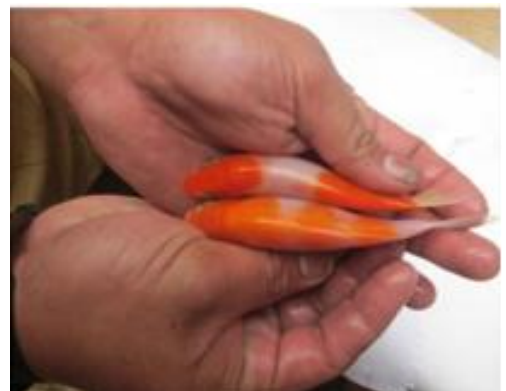

Atas (menggunakan spirulina) bawah (tanpa spirulina)

Gambar 4 Hasil kegiatan pendederan ikan koi dengan membandingkan warna dengan penggunaan dan tanpa penggunaan spirulina.

penyuluhan dan IbM ini bermanfaat bagi khalayak sasaran. Para peserta yang sebagian besar merupakan pelaku budi daya ikan koi menjadi lebih memahami dan dapat mempraktikkan pemanfaatan spirulina yang digunakan sebagai pakan ikan koi yang mereka budidayakan.

\section{Prospek Peningkatan Ekonomi dengan Formulasi Pakan Ikan dengan Spirulina}

Penggunaan spirulina dalam pakan ikan koi memiliki peluang meningkatkan penghasilan para pembudidaya ikan hias di Cisaat Sukabumi. Berdasarkan kualitas hasil pendederan ikan koi yang diberi pakan spirulina, terlihat kualitas warnanya meningkat dan semakin cemerlang. Pengamatan secara visual oleh para pembudidaya menunjukkan bahwa kualitas warna koi yang diberi pakan spirulina termasuk Grade A, di mana harga jualnya meningkat dari semula $\mathrm{Rp}$ 3.000 menjadi Rp 4.500-6.000 per ekor, dengan harga tersebut dikalikan jumlah ikan setiap masa pendederan yang jumlahnya sekitar 4.000 ekor per pendederan, maka keuntungan yang didapatkan sekitar 20 juta per siklus, sementara tanpa spirulina hanya meraup keuntungan 12 juta per siklus.

\section{SIMPULAN}

Penggunaan pakan berbahan tambahan serbuk spirulina pada ikan koi di Pokdakan PBC Fish Farm terbukti dapat meningkatkan kualitas warna, serta memberikan nilai tambah ekonomi sebesar $50-100 \%$ di mana harga jualnya meningkat dari semula Rp 3.000 menjadi Rp 4.5006.000 per ekor. Kegiatan pengabdian kepada masyarakat di Pokdakan PBC Fish Farm di Desa Nagrak, Kecamatan Cisaat, Kabupaten Sukabumi tentang penggunaan spirulina dalam pakan ikan koi mendapatkan respons dan hasil yang baik dari peserta penyuluhan. Terlihat adanya perubahan dan penerimaan yang baik terhadap teknologi yang diperkenalkan, dan diharapkan akan diperoleh suatu penguatan pemberdayaan ekonomi bagi anggota kelompok pembudidaya ikan hias khususnya dan masyarakat sekitar pada umumnya.

\section{UCAPAN TERIMA KASIH}

Kami mengucapkan terima kasih kepada Kemenristek Dikti yang telah membantu terlaksananya kegiatan ini melalui Hibah Ipteks Bagi Masyarakat (IbM) Tahun 2016.

\section{DAFTAR PUSTAKA}

Amin MI. 2012. Peningkatan Kecerahan Warna Udang Red Cherry (Neocaridina heteropoda) Jantan melalui Pemberian Astaxanthin dan Canthaxanthin dalam Pakan. Jurnal Perikanan dan Kelautan. 4(3): 243-252.

Budi IM. 2001. Kajian Kandungan Zat Gizi dan Sifat Fisiko Kimia Berbagai Jenis Minyak Buah Merah (Pandanus conoideus) Hasil Ekatraksi Secara Tradisional di Kabupaten Jayawijaya Irian Jaya. [Tesis]. Bogor (ID): Institut Pertanian Bogor.

Effendie MI. 1979. Metode Biologi Perikanan. Bogor (ID): Yayasan Dewi Sri. 112 hlm.

James R. 2010. Effect of dietary Supplementation of Spirulina on Growth and Phophatase Activity in Copper-Exposed Carb (Labeo rohita). The Israel Journal of Aquaculture Bamidgeh. 62(1): 19-27. 
Hidayat N, Saati EA. 2006. Membuat Pewarna Alami. Cetakan I. Surabaya (ID): Trubus Agrisarana. $52 \mathrm{hlm}$.

Kusuma DM, Rosidah, Afrianto E, Sukarman, Priyadi A. 2012. Pengaruh Penambahan Tepung Bunga Marigold Dalam Pakan Buatan Terhadap Kualitas Warna, Kelangsungan Hidup Dan Pertumbuhan Benih Ikan Mas Koki (Carassius auratus). Jurnal Perikanan Kelautan. 3(4): 221-230.

Lesmana DS. 2007. Budidaya Ikan Hias Air Tawar Populer. Jakarta (ID): Penebar Swadaya.

Murtidjo, Bambang A. 2011. Beberapa Metode Pembenihan Ikan Air Tawar. Cetakan ke-7. Yogyakarta (ID): Kanisius. $109 \mathrm{hlm}$.

Noviyanti K, Tarsim, Maharani HW. 2015. Pengaruh Penambahan Tepung Spirulina Pada Pakan Buatan Terhadap Intensitas Warna
Ikan Mas Koki (Carassius Auratus). Jurnal Rekayasa dan Teknologi Budidaya Perairan. 3(2): 411-415.

Sasson A. 1991. Culture of microalgae in achievement and evaluation. United Nation Educational, Scientific and Cultural Organitation (UNESCO) Place de Pontenry: Paris, France (FR). 104p.

Tongsiri S, Mang-Amphan K, Peerapornpisal Y. 2010. Effect of Replacing Fishmeal with Spirulina on Growth, Carcass, Composition and Pigment of the Mekong Giant Catfish. Asian Journal of Agricultural Science. 2(3): 106-110.

Vonshak A. 1997. Appendics: Spirulina platensis (Arthrospira): Physiology cell-biology and biotechnology. London (GB): Taylor and Francis Ltd. pp: 214. 